\title{
Rebel Leaders, Internal Rivals, and External Resources: How State Sponsors Affect Insurgent Cohesion
}

\author{
Henning Tamm \\ School of International Relations \\ University of St Andrews \\ ht37@st-andrews.ac.uk
}

To be published in International Studies Quarterly

\section{AUTHOR ACCEPTED MANUSCRIPT - NOT THE FINAL VERSION. PLEASE DO NOT CITE OR CIRCULATE WITHOUT THE AUTHOR'S PERMISSION.}

\begin{abstract}
:
Civil wars often feature insurgent groups with external sponsors. Yet we know little about the impact of such sponsorship on insurgent cohesion. Indeed, researchers disagree about the conditions under which state sponsorship encourages or discourages organizational splits. This article presents a theory that reconciles these disagreements. I focus on how the allocation of external resources affects the intra-group distribution of power between rebel leaders and their internal rivals. Sponsors that help maintain an imbalance of power in favor of the leader foster cohesion; those that help flip the imbalance in favor of a rival increase the likelihood of an internal coup within the group. Only when sponsors contribute to a shift from an imbalance of power to balanced power is the rebel group more likely to split into competing organizations. I further argue that sponsors reallocate their resources in favor of a rebel leader's internal rival in order to punish the leader for undesired behavior. Case studies of two major insurgent groups-the Sudan People's Liberation Movement/Army and the Lebanese Hezbollah-illustrate the explanatory power of my argument.
\end{abstract}

\section{Author's note:}

For helpful comments on earlier versions of this paper, I thank Ben Ansell, Chris Butler, Seamus Duggan, Ferdinand Eibl, Corinna Jentzsch, Zoe Marks, Lee Seymour, Duncan Snidal, Taylor St John, Kathrin Tamm, the anonymous reviewers and the ISQ editorial team, as well as audience members at the IR Research Colloquium in Oxford, the 2015 Annual Convention of the International Studies Association, and the 2015 Annual Meeting of the American Political Science Association. 
Nearly half of all rebel groups active after the Second World War are believed to have received support from foreign states, typically in the form of military assistance (Cunningham, Gleditsch, and Salehyan 2013, 527). Existing research shows that such outside interference tends to prolong civil wars (Cunningham 2010, 124) and make them more deadly (Heger and Salehyan 2007, 396). Meanwhile, the impact of external sponsorship on the organizational cohesion of rebels remains poorly understood (Pearlman and Cunningham 2012, 11-2). Some scholars argue that individual state sponsors foster insurgent cohesion (Sinno 2008, 34), whereas multiple sponsors contribute to fragmentation (Lichbach 1995, 205; Pearlman 2011, 19-20). ${ }^{1}$ Another study claims the exact opposite (Lidow 2011, 87, 104). A third perspective suggests that the effect of foreign support depends on the social bases of insurgent groups (Staniland 2012, 154-5). Since civil wars with more than one rebel group prove particularly difficult to resolve (Cunningham 2011, 15), scholars and policymakers need to understand the relationship between external state sponsorship and insurgent fragmentation.

This article advances a theory that reconciles existing disagreements and, in doing so, provides a better understanding of the conditions under which state sponsors encourage or discourage splits in rebel groups. It focuses on how these sponsors affect the distribution of power between a rebel leader and an internal rival by allocating external resources to the leader, to the rival, or to both. I argue that, first, the more state sponsors help reinforce an imbalance of power that favors an existing rebel leader, the more they strengthen organizational cohesion. Second, the more state sponsors contribute to inverting an imbalance of power so that it favors a rival, the more likely an internal coup becomes. ${ }^{2}$ Third, the more state sponsors contribute to balancing power between a leader and a rival, the more they encourage group fragmentation. In essence, the rival becomes strong enough to defy the leader but remains too weak to overthrow him. ${ }^{3}$

The external resources that empower internal rivals sometimes come from targeted governments bent on "exploiting local rivalries to fragment the opposition" (Seymour 2014, 104). Here, however, I focus on the most common provider of external resources: foreign states. Such states are typically involved in the early stages of a rebel group's emergence. They often help individuals establish themselves as rebel leaders. Building on principal-agent

\footnotetext{
${ }^{1}$ This article uses "fragmentation" as a synonym for split(s), both referring to the splitting of an organization into two or more separate ones. For an alternative conceptualization that focuses on fragmentation within a movement of rebel organizations, see Bakke, Cunningham, and Seymour (2012, 266-8).

${ }^{2}$ Internal coups should not be seen as instances of fragmentation. Even Christia (2012, 45, fn. 19), who considers both coups and splits as forms of "fractionalization," concedes that "in actuality, a takeover is an in-group transformation."

${ }^{3}$ I use male pronouns because all the rebel leaders and internal rivals discussed in this article are men.
} 
theory, I argue that foreign sponsors usually choose to support those individuals whose preferences they believe to align with their own. However, sponsors sometimes also support leaders with more divergent preferences. They do so in order to destabilize a rival regime or influence the course of an insurgency. Regardless of the initial level of preference alignment, the strategic priorities of rebel leaders and state sponsors can change over time. As a result, the rebel leader may engage in actions that seriously deviate from the sponsors' interests. This undesired behavior - known as agency slack - in turn leads sponsors to redirect external resources to a leader's internal rival.

I first review the three contradictory perspectives on the link between state sponsorship and insurgent cohesion that emerge from the existing literature. In the second section, I use about a dozen illustrative examples from across the world, as well as descriptive statistics from cross-national datasets on external support and organizational splits, to develop my arguments in greater detail. I also address the theory's scope conditions, highlighting that sponsors generally find it easier to foster splits than to ensure cohesion. This is because internal rivalries are commonplace-even within groups that exhibit military effectiveness.

The third section illustrates the explanatory power of the theory by providing case studies of two major insurgent groups whose organizational trajectories cannot be accounted for by existing explanations. Combining congruence tests with process tracing, I show that the variation in the cohesion and fragmentation of the Sudan People's Liberation Movement/Army (SPLM/A) and the Lebanese Hezbollah is best explained by changes in the allocation of external resources. The concluding section discusses the significance of these findings and their implications for future research. It also highlights why policymakers involved in attempts to resolve civil wars need to take into account the effects that state sponsors have on rivalries within rebel groups.

\section{State Sponsorship and Insurgent Cohesion: Three Contradictory Perspectives}

In recent years, several civil war scholars have turned their attention to the meso level of analysis. They focus on structural characteristics of rebel groups, as well as the dynamics within and between them, rather than on countrywide factors or on individual motivations to rebel (Pearlman and Cunningham 2012, 5-6). One of the most important challenges in this context is to explain why some rebel groups remain cohesive collective actors over long periods of time while others splinter into rival organizations. Cohesion here refers to a group's 
"structural integrity," not to its military effectiveness. ${ }^{4}$ Conversely, insurgent fragmentation-or, synonymously, a rebel group split—denotes an event in which part of a group refuses to recognize the existing leader's command authority and breaks away to form a separate organization with its own leadership and chain of command. ${ }^{5}$ The size of such splits varies widely. In his research on Northern Ireland and Myanmar, Kenny (2010, 548-9) finds one split in which around half of all group members broke away, whereas only three to five percent of members split off in the other seven cases.

The existing literature has paid relatively little attention to the role of state sponsorship in accounting for variation in insurgent cohesion. However, we can identify three contradictory perspectives. First, Sinno $(2008,34,79)$ argues that an individual sponsor wishes to exert control over the group it supports and therefore encourages organizational centralization by channeling resources to the rebel leader. Centralization, in turn, should increase cohesion. Scholars also suggest that competition among multiple external patrons makes the fragmentation of a rebel group more likely, as one of them may "give opposition factions the resources to act independently of the official leadership" (Pearlman 2011, 19; see also Lichbach 1995, 205). I return to this important point in the next section.

A second perspective comes to opposite conclusions. It links single state sponsors to a higher probability of insurgent fragmentation than multiple ones. Lidow (2011) assumes that external state sponsors tend to care more about being able to control a rebel group than about the group's military effectiveness. Consequently, he argues, a state chooses to sponsor a relatively weak rebel leader who struggles to maintain control over his top commanders in the absence of significant outside backing (Lidow 2011, 103-4). In the case of multiple state sponsors, however, Lidow's $(2011,87-8)$ formal model suggests that the rebel leader gains some leverage over his patrons and thus receives more resources. This makes fragmentation less likely.

The third perspective shifts the focus from the motives and number of state sponsors to the social underpinnings of insurgent organizations. Staniland $(2012,142)$ argues that the impact of material resources-including those from state sponsorship-on insurgent cohesion fundamentally depends on "the structure of the preexisting social networks upon which an armed group is built." He distinguishes two types of rebel groups. "Integrated groups" are founded upon "overlapping social bases." They combine strong horizontal ties among organ-

\footnotetext{
${ }^{4}$ By contrast, Kenny (2010, 535), who highlights this distinction, uses "cohesion" and "disintegration" for military (in)effectiveness, and "structural integrity" and "fragmentation" for (the absence of) organizational splits.

${ }^{5}$ This definition builds on Bakke et al. (2012, 268); Lidow (2011, 98); Sinno (2008, 35).
} 
izers from different localities with strong vertical ties that embed these leaders in their respective local communities. By contrast, "fragmented groups" are built on "divided social bases," characterized by weak horizontal ties, weak vertical ties, or both (Staniland 2012, 150-1). ${ }^{6}$ The key to explaining splits and leadership feuds accordingly lies in horizontal ties: the weaker they were prior to the group's creation, the more likely they are to prevent centralization and result in internal conflict (Staniland 2012, 154).

\section{The Impact of External Resources on the Distribution of Power Within Rebel Groups}

It is important to understand whether a rebel group is structurally predisposed to fragmentation. Focusing solely on social bases, however, risks underestimating the extent to which state sponsors can actively influence the organizational consequences of their material support. In his book, Staniland $(2014,38,50)$ in fact concedes that state sponsors can encourage "factional fusing"- that is, a strengthening of horizontal ties - or even impose a "forced merger," and that, conversely, they can also "undermine cohesion by exploiting divisions between factions." But these observations are undertheorized and clearly secondary, if not contradictory, to the book's main focus on the explanatory power of social bases.

By contrast, this section puts the active role of state sponsors front and center. It also reconciles the existing disagreements about the impact of single vis-à-vis multiple sponsors. I propose a new theory that links the allocation of external resources to the intra-organizational distribution of power between a rebel leader and an internal rival. ${ }^{7}$ Power is understood here as a relational concept, measuring the leader's and the rival's relative shares of the military resources under their control. ${ }^{8}$ I first show that intra-group contention is commonplace and highlight the conditions that enable rivals to defy their leaders. Explaining both why state sponsors choose to support leaders and why they sometimes shift their support to rivals, I then specify hypotheses about the effect of external resources on insurgent cohesion.

\footnotetext{
${ }^{6}$ In his book, Staniland $(2014,5-8)$ further distinguishes this type into vanguard (strong horizontal, weak vertical ties), parochial (weak horizontal, strong vertical ties), and fragmented (both ties weak).

7 This differs from studies focusing on the inter-organizational distribution of power within rebel movements (Bakke et al. 2012, 271-2; Krause 2013/2014, 75-7). Throughout this section, I use "rival" in the singular simply for expositional purposes; in reality, a leader may face a group of rivals working together, such as Lam Akol and Riek Machar in the SPLM/A case study.

${ }^{8}$ Control over military resources implies not only materiel but also personnel, in the sense of commanding the loyalty of troops who put that materiel to use. On relative (latent or military) power, see Glaser (2010, 41-2).
} 


\section{Internal Rivals and the Conditions for Coups or Splits}

Elite disagreements within rebel groups are the norm, not the exception. While many of them can be contained (violently or nonviolently), others result in defections, organizational splits, or internal coups. The average intensity of elite-level rivalries is likely to be higher in what Staniland (2014, 5-6) calls fragmented and parochial groups than in vanguard and integrated ones, as central processes of control are more fragile. However, even groups that Staniland $(2014,6$, 59) characterizes as integrated, such as Hezbollah in Lebanon-discussed further below-and the Hizbul Mujahideen in Kashmir, have suffered from internal rivalries. The Hizbul Mujahideen witnessed three minor splits in the 1990s and a major set of defections in 2002, when a senior commander was expelled and took several militants with him (Staniland 2014, 85-9). ${ }^{9}$

Internal rivalries also affected groups that later went on to seize state power. The Sandinista National Liberation Front in Nicaragua "came apart in a bitter, three-way factional dispute over how to fight the regime" in 1975-1976 (Gilbert 1988, 8). The Tigray People's Liberation Front in Ethiopia saw the departure of its former chairman, Aregowie Berhe, after a tense stand-off with the new leadership in 1984 (Young 1997, 138).

In short, one can reasonably assume that (latent) rivalries exist in almost all rebel groups, even in those that are highly effective on the battlefield. The main question, therefore, is under which conditions rivalries escalate into internal coups or organizational splits. I argue that these outcomes critically depend on changes in the distribution of military resources between a rebel leader and an internal rival. A leader's command authority is generally based on an imbalanced distribution of power in his favor. If this imbalance gets radically inverted in favor of a rival, the latter is likely to be able to stage a successful coup, thus replacing the existing leader without necessarily undermining the group's structural integrity. ${ }^{10}$ By contrast, the shift from an imbalance to a more balanced distribution of power increases the likelihood of a split. The rival becomes strong enough to actively challenge the leader but remains too weak to replace him.

In terms of internal resources, a rival most likely has a significant following within a rebel group if he is an ethnic leader and/or regional commander. These followers may enable him to challenge the rebel leader. According to one of the first cross-national studies on insurgent fragmentation, the "faction that split off had a regional identity distinct from that of

\footnotetext{
${ }^{9}$ Staniland $(2014,88-9)$ calls these defections "a major split," but since the commander "never formed a new organization," this episode does not meet my definition of a split.

${ }^{10}$ For a similar argument focused on the relative power of ethnoregional subgroups, see Christia $(2012,45)$.
} 
the main group" in $43(81 \%)$ of the 53 cases for which data was available (Christia 2012, $227,286-92){ }^{11}$ The study suggests that rebel organizations typically are heterogeneous in composition, and that, if push comes to shove, the loyalty of rank-and-file members will be with their subgroup leaders (Christia 2012, 42-4).

Whereas Christia argues that severe battlefield losses tear different subgroups apart, I propose an alternative mechanism for coups or splits-a change in the distribution of external resources in favor of an internal rival. For the rival, these resources represent "factors in the environment that visibly and proximately open up the prospect of success" (Tarrow 2011, 164). They can come either from external state sponsors offering support to the rival in exchange for a revolt against the rebel leader or, counterintuitively, from the very government that the rebel group is fighting. In the latter scenario, the rival splits off from the group and simultaneously switches sides in the conflict "in exchange for arms, ammunition, supplies, and military backing" (Seymour 2014, 104). Such a split thus results in the creation of a progovernment militia (Carey, Mitchell, and Lowe 2013, 253). The Sudanese regime used this strategy in numerous cases in both southern Sudan and Darfur (Seymour 2014, 107), as shown in the SPLM/A case study further below. Before discussing the more common scenario, in which external state sponsors support an internal rival, I address why they usually back the leader of a rebel group and how that affects insurgent cohesion.

\section{External State Sponsorship of Rebel Leaders}

Scholars often analyze relations between state sponsors and rebel groups through the lens of principal-agent theory (Hovil and Werker 2005; Byman and Kreps 2010; Salehyan 2010; Bapat 2012). The underlying idea is that sponsors face a trade-off: while supporting the domestic opponents of a rival regime tends to be less costly than engaging in direct warfare, the delegation of conflict also entails certain strategic risks (Salehyan, Gleditsch, and Cunningham 2011, 712-5). In particular, sponsors have to worry about a rebel leader's agency slack, that is, "independent action by an agent that is undesired by the principal" (Hawkins, Lake, Nielson, and Tierney 2006, 8).

Given these worries, Lidow $(2011,103-4)$ suggests that states prefer to sponsor the emergence of rebel groups with weak leaders. Such leaders cannot afford to lose their principal's support and thus are least likely to engage in undesired behavior. However, Lidow $(2011,70)$ also concedes that "[w]hen states can find a compatible partner who shares a

\footnotetext{
${ }^{11}$ Christia also codes splits in the armed forces of states; I deleted these and all pre-1945 splits-leaving 75 observations, with data on the regional subgroup available for $53(71 \%)$ of them- to arrive at the reported figures.
} 
strong attachment to the state's ideological, political, or ethnic goals, states are more inclined to support charismatic, trustworthy leaders who can mobilize a strong base of support." In this context, I hypothesize that state sponsors striving for regime change in the target state are particularly keen to ensure insurgent cohesion, as their preferences are well aligned with those of the rebel leader. Pakistan, for instance, began to support Mullah Omar's Taliban in the mid-1990s "with the objective of a Pashtun outright victory" in Afghanistan's civil war (Christia 2012, 75). It was joined in this endeavor by Saudi Arabia (Rashid 2010, 48, 2012). ${ }^{12}$ This example also illustrates that multiple sponsors foster cohesion as long as they all allocate their resources to the rebel leader, thereby creating or reinforcing an intraorganizational imbalance of power in his favor.

More generally, state sponsors need to balance their desire to control a rebel group with the need to find a rebel leader who is capable of delivering on his promises (Sinno 2008, 7980; Salehyan et al. 2011, 714-5). There is thus little reason to assume that sponsors typically prefer to support weak leaders. In most cases, state sponsors are involved in the initial creation-or at least proper emergence-of rebel groups. According to the UCDP External Support Dataset, 129 (84\%) of the 153 non-state armed groups that received state support already had such support in the first year of their appearance in the dataset, which covers the period from 1975 to 2009 (Högbladh, Pettersson, and Themnér 2011). State sponsors can thus often screen potential leaders early on and help their preferred candidate establish himself as the group's leader (Salehyan 2010, 505).

In some cases, however, sponsors support rebel leaders simply because an opportunity to destabilize rival regimes presents itself (Byman et al. 2001, 32-3). In the wake of Saddam Hussein's fall, "Iran was not looking for a militia capable of taking over the Iraqi government, but rather an ally capable of knocking the government, and its American suitor, off its bearings" (Felter and Fishman 2008, 35). In other cases, sponsors support rebel leaders primarily because they seek to influence the course of an insurgency (Byman et al. 2001, 34-5). Examples include Pakistan's backing of Kashmiri leaders and Syria's support for Palestinian leaders (Kapur and Ganguly 2012, 126-7; Byman and Kreps 2010, 11). In both scenariosopportunism and influence seeking - the preferences of state sponsors and rebel leaders are not necessarily aligned, making disagreements between them more likely. I return to these cases further below.

\footnotetext{
${ }^{12}$ Further examples are listed in Byman, Chalk, Hoffman, Rosenau, and Brannan (2001, 24-30, 33-4).
} 
Since internal rivalries within rebel groups are commonplace, state sponsors generally find it much more difficult to ensure insurgent cohesion than to foster splits. In the case of the National Patriotic Front of Liberia (NPFL), for example, Charles Taylor "emerged as the group's president only because he was the one with the best foreign contacts" (Ellis 1998, 158). Despite Taylor's backing by Burkina Faso, Côte d'Ivoire, and Libya, however, special forces commander Prince Johnson managed to break away with merely around thirty-five soldiers. He established the Independent NPFL (INPFL) in February 1990, just weeks after the NPFL's first incursion into Liberia (Ellis 1999, 2-3; Lidow 2011, 151). A closer look at the events leading to the split reveals the intricacies of external resource flows: "A weapons shipment from the Ivorian military was delayed for several weeks because the NPFL lacked money to hire trucks to transport the munitions," which Johnson saw as a sign of Taylor's weakness (Lidow 2011, 172).

State sponsorship of a rebel leader is likely to counteract factors that increase the chance of fragmentation—such as weak horizontal ties or severe battlefield losses—only if the level of external resources allocated to the leader is very high. This scope condition is met most clearly when sponsors provide troop support. My argument would thus be falsified by splits of rebel groups whose leaders benefit from external troop deployments while their internal rivals receive no external support. ${ }^{13}$ Existing datasets, however, reveal no such cases. Between 1945 and 2011, foreign states sent troops to fight alongside 25 (16\%) of the 152 rebel groups that received explicit military support (Cunningham et al. 2013). I cross-referenced these 25 groups with the UCDP Actor Dataset, which codes whether an actor emerged out of an organizational split (Uppsala Conflict Data Program 2014). Only two of the groups appear to have suffered fragmentation. In both cases, the splits were enabled by the provision of external resources to internal rivals. ${ }^{14}$

\section{External State Sponsorship of Internal Rivals}

State sponsors allocate resources to a rebel leader's internal rival in order to punish the leader for undesired behavior. Even if the preferences of sponsors and rebel leaders are relatively

\footnotetext{
${ }^{13}$ Timing is important here. While Burkina Faso sent around 700 soldiers in support of Taylor's NPFL-a case overlooked by Cunningham et al. (2013) - it seems that these troops arrived only after Johnson's split (Englebert 1996, 158-60).

${ }^{14}$ The two cases are the split of the Congolese Rally for Democracy (RCD) in the Democratic Republic of Congo, which was due to disagreements between Rwanda and Uganda (Prunier 2009, 220-3), and the breaking away of the Democratic Revolutionary Council (CDR) from the Libyan-sponsored Transitional Government of National Unity (GUNT) in Chad. The CDR was itself "supplied by the government of Libya and personally directed by Colonel Qaddafi” (Burr and Collins 1999, 119; see also Nolutshungu 1996, 148-9, 192-3).
} 
well aligned at the outset, either side's strategic priorities may shift over time, ultimately resulting in agency slack. International pressure or a change in government can lead a sponsor to reconsider its foreign policy, but a rebel leader may refuse to adjust his behavior accordingly. In the case of multiple sponsors, the emergence of disagreements between them effectively forces a rebel leader to take sides and thus disobey at least one of the sponsors. On the other hand, the lessons that a rebel leader draws from battlefield outcomes can make him either less or more ambitious than a sponsor desires. The following discussion illustrates these different causes of agency slack while focusing on its consequences for insurgent cohesion. ${ }^{15}$

If a rebel leader's undesired behavior leads state sponsors to divide their resources among the leader and an internal rival, thus contributing to a more balanced distribution of power, the likely outcome is an organizational split. Divided support can occur independently of whether a rebel group has a single sponsor or multiple ones. A single sponsor divides its resources if it wants to punish a leader's agency slack and increase its options through a breakaway group but still considers the leader a valuable ally. Iran helped Qais Khazali and other commanders of Muqtada al-Sadr's Mahdi Army in Iraq to form splinter groups even as it continued to support al-Sadr himself. The Najaf crisis in 2004 had shown the Iranians that al-Sadr, emboldened by events on the battlefield (International Crisis Group 2006, 11), was as unreliable as he was useful (Felter and Fishman 2008, 34-5, 44-5).

An example of multiple sponsors dividing their resources can be found in the Fateh split of 1983: Syria and Libya reallocated their resources to Said al-Muragha's uprising against Fateh leader Yasir Arafat, while Jordan and other Arab states continued to back Arafat. Drawing lessons from Fateh's involvement in the Lebanese civil war, Arafat had launched a new diplomatic strategy that was at odds with Libyan and Syrian interests (Sayigh 1997, 55165; Pearlman 2011, 89-90).

If agency slack leads state sponsors to withdraw their resources from a rebel leader and instead unite them behind an internal rival, the likely outcome is either a coup by the rival or-if the leader manages to retain significant internal resources—an organizational split. State sponsors can only invert an intra-group imbalance of power and achieve a coup if there is a rival who, given enough external resources, can rally the group's key commanders behind him. This criterion does not depend on material resources alone. Pakistan supported the rise of the Jammu and Kashmir Liberation Front (JKLF) even though the group's goal was

\footnotetext{
${ }^{15}$ State sponsors sometimes punish a rebel leader's agency slack by terminating their support for the leader's group as a whole and/or by providing support to another group from the same country. Since the impact of a loss of external resources is less determinate than that of a reallocation favoring an internal rival, the discussion here focuses only on the latter.
} 
Kashmiri independence (Kapur and Ganguly 2012, 126-7). When "[m]ost of its leaders and prominent activists could not be persuaded, in spite of repeated efforts, to renounce the idea of independence" and instead to favor accession to Pakistan, Islamabad ended its support for JKLF's central leadership and helped some of its less ideologically principled, and thus “more pliable," commanders to form pro-Pakistani splinter groups (Bose 2007, 238).

By contrast, Rwanda successfully orchestrated a coup within the National Congress for the Defense of the People (CNDP) in the Democratic Republic of Congo. Laurent Nkunda was toppled by Bosco Ntaganda, his chief of staff. Ntaganda managed to hold the group together while leading it into a peace deal negotiated among the Congolese and Rwandan governments. Encouraged by success on the battlefield, Nkunda "had become too autonomous and thus "uncontrollable"” (Vlassenroot and Raeymaekers 2009, 482). This turned him into "an embarrassment and a liability" for Rwanda, which faced increasing international pressure to stop supporting him (International Crisis Group 2009, 9). Hezbollah's nonviolent leadership change in 1991 provides another example in which a sponsor, Iran, effectively organized an internal coup. The change in government following Ruhollah Khomeini's death led to a more pragmatic Iranian foreign policy, to which Hezbollah's radical leader Subhi al-Tufayli proved unwilling to adjust, as discussed in the case study below.

In sum, the impact of state sponsorship on the cohesion of a rebel group depends on the overall allocation of external resources. If state sponsors create or reinforce an imbalance of power that favors a rebel leader, organizational cohesion becomes more likely. By contrast, the more state sponsors empower an internal rival, the greater the likelihood of intra-group contentious action becomes. If such a provision of resources radically alters the distribution of power so that it favors the rival, the likely outcome is an internal coup; otherwise, it is more likely that an organizational split occurs. Furthermore, state sponsors generally find it easier to foster splits than to ensure cohesion. Their support for internal rivals results from agency slack by rebel leaders.

\section{Two Illustrations: Insurgent Cohesion and Fragmentation in Sudan and Lebanon}

\section{Research Design and Methodology}

This section analyzes the evolution of two major insurgent groups-one from Sudan, the other from Lebanon - to illustrate the relative explanatory power of the theory introduced above. As Table 1 shows, I selected the two cases, which each comprise two periods, on the basis that major existing explanations fail to account for variation in organizational cohesion over time. I chose two groups with contrasting social bases to show that state sponsors can over- 
come a group's structural predisposition regardless of whether it is geared towards cohesion or fragmentation. The SPLM/A was built upon divided social bases, yet it proved militarily successful and did not splinter between 1983 and 1990. While battlefield performance predicts the SPLM/A's initial period of cohesion, and social bases predict its eventual fragmentation, only external resources correctly predict both outcomes. In 1991-1992, a significant shift occurred in the allocation of such resources. ${ }^{16}$ In the case of Hezbollah, all three theories point to the group's cohesion in the period from 1991 to 1996, but only external resources can explain the fragmentation that took place over the subsequent three years. ${ }^{17}$

TABLE 1. Case Studies: Congruence Tests (bold cells are correct predictions)

\begin{tabular}{llll}
\hline & Social Bases & Battlefield Performance & External Resources \\
\hline SPLM/A, 1983-90 & Fragmentation & Cohesion & Cohesion \\
SPLM/A, 1991-92 & Fragmentation & Cohesion & Fragmentation \\
\hline Hezbollah, 1991-96 & Cohesion & Cohesion & Cohesion \\
Hezbollah, 1997-99 & Cohesion & Cohesion & Fragmentation \\
\hline
\end{tabular}

The case studies thus illustrate that external resource allocation can account for variation left unexplained by existing theories. However, two cases alone cannot provide conclusive evidence as to whether my theory generally outperforms others; they merely suggest that it is worth testing the theory more systematically against the wider universe of cases. I discuss the challenges of such an undertaking in the conclusion.

Although the two cases were selected because of their contrasting social bases and their within-case variation in the allocation of external resources, they also provide variation with regard to the level of external resources. The cross-border support that the SPLM/A received from Ethiopia, its main sponsor, fell short of troops, whereas Hezbollah was assisted by a small contingent of Iranian Revolutionary Guards and operated in the context of a large Syrian occupation force. This makes the SPLM/A a harder case for my theory than Hezbollah. It also shows that the theory's ability to outperform others is not simply an artifact of the direct intervention of sponsors.

\footnotetext{
${ }^{16}$ Battlefield performance refers to the argument that battlefield wins foster cohesion while significant losses lead to fragmentation (Christia 2012,8). Woldemariam $(2016,136-8)$ makes a similar argument, but in contrast to Christia, he suggests that battlefield gains also increase the chance of fragmentation, thus concluding that only battlefield stalemates foster cohesion. In the cases at hand, I found no support for Woldemariam's claim.

${ }^{17}$ Hezbollah emerged in 1982 (Ranstorp 1997, 25-6). I focus on its evolution after the 1991 leadership change because that period most clearly illustrates the distinctive explanatory power of external resource allocation.
} 
By complementing the congruence tests shown in Table 1 with process tracing, the case studies evaluate how much evidence there is for each causal mechanism posited by a theory that correctly predicts an outcome (George and Bennett 2005, 181-3). A wide range of material exists on both insurgent groups, providing the kind of "diverse and relevant evidence" that is required for process tracing (Bennett and Checkel 2015, 27). These sources include insider accounts that, despite their obvious biases, offer important insights. I draw on books written by an SPLM/A internal rival and one of his coconspirators (Akol 2001; 2003; Nyaba 2000), and by Hezbollah's long-term deputy secretary-general (Qassem 2010).

Table 1 only shows the two existing explanations discussed in the theory section. However, I ruled out omitted variable bias as far as I could by also considering other arguments from the literature on insurgent cohesion and fragmentation, including those that focus on the role of foreign fighters (Bakke 2014), geography and technology (Johnston 2008), peace negotiations (Pearlman 2008/2009; Olson Lounsbery and Cook 2011), and state repression (McLauchlin and Pearlman 2012; Schubiger 2015). Since none of them can account for the variation in the organizational trajectories of the SPLM/A and Hezbollah, and given space constraints, I do not discuss these arguments in the case studies. In terms of process tracing methodology, I thus initially cast "the net widely for alternative explanations" (Bennett and Checkel 2015, 23) but then opted for a more "efficient" presentation that focuses on my argument and its two main alternatives (Schimmelfennig 2015, 108).

\section{Suppressing Internal Rivals: Ethiopia's Impact on the SPLM/A, 1983-1990}

The second Sudanese civil war began in May 1983 with a series of army mutinies in the south that culminated in the SPLM/A's foundation (LeRiche and Arnold 2012, 61-2). Many of the mutineers previously fought for the southern Anya-Nya rebel movement in Sudan's first civil war, lasting from 1955 until 1972, and had subsequently been integrated into the national army. When the mutineers and several smaller bands of southern guerrillas, which had sprung up over the previous decade and were collectively known as Anya-Nya II, came together in western Ethiopia in mid-1983 to create the SPLM/A, a leadership dispute occurred between Akuot Atem, Samuel Gai Tut, and John Garang. Due to Ethiopian backing, Garang won out, leading the others to retreat to Sudan with their Anya-Nya II troops (Johnson and Prunier 1993, 120-6). However, there was "no initial split" in an organizational sense (Madut-Arop 2006, 75). Atem and Gai Tut had "kept their units separate from the main body of the newly formed SPLA" (Johnson 2011, 65). 
The failed merger meant that the SPLM/A spent its first few years fighting both the northern-dominated Sudanese army and the Anya-Nya II, as well as pro-government militias (Johnson and Prunier 1993, 126-31). It nevertheless made impressive territorial gains throughout the 1980s, controlling nearly ninety percent of the rural south by 1989 (Lesch 1998, 91). This military success and the group's cohesion until 1991 are all the more remarkable given frequent disagreements among its military officers as well as between them and political representatives (Nyaba 2000, 45-6). Two internal rivalries stood out in the 19831990 period. In 1987, Kerubino Kuanyin Bol, Deputy Chairman of the SPLM and Deputy Commander-in-Chief of the SPLA, challenged Garang's leadership and was subsequently arrested in Addis Ababa (Madut-Arop 2006, 203). One year later, Arok Thon Arok, SPLA Deputy Chief of Staff for Logistics and Administration, was imprisoned for insubordination after planning a coup and establishing personal contacts with the Sudanese government (Akol 2001, 262-4). The following discussion shows that external resource allocation best explains why these rivalries did not result in organizational splits.

The social bases argument fails to predict the SPLM/A's long period of cohesion from 1983 to 1990 . Young $(2012,63,64)$ notes "the highly decentralized and tribal character of southern Sudanese society," and argues that, "in the absence of a strong ideology and institutions, tribalism became the mainstay of the SPLM/A." Madut-Arop $(2006,189)$ describes the SPLM/A's divided social bases in even starker terms, writing that "its constituents and cadres were composed of incongruous, unmatchable, and uncompromising groups." These assessments were shared by SPLM/A insiders, with Nyaba $(2000,71,67)$ deploring that "political and ideological bonds were weak," and that the group's internal contradictions "were more dangerous to its survival than the combined might of its many external enemies." The SPLM/A was multi-ethnic from the start, initially comprising mostly of Dinka, Nuer, and Shilluk (LeRiche and Arnold 2012, 61). Furthermore, Garang gave local commanders a lot of autonomy (Johnson 2011, 92), increasing the likelihood of splits along weak horizontal ties.

Contrary to social bases, the battlefield performance argument-that "battlefield wins will foster intragroup cohesion" (Christia 2012, 8)—correctly predicts the SPLM/A's trajectory between 1983 and 1990. As noted above, the group was militarily successful throughout that period. However, the evidence for the purported mechanism proves at best mixed. Christia $(2012,8)$ suggests that subgroups have stronger in-group than cross-group bonds. Yet Garang and his two main internal rivals were actually all from the Dinka ethnic group: Kerubino was a Dinka from Bahr al-Ghazal in today's western South Sudan, and Arok was a Twic Dinka from eastern South Sudan, just like Garang himself (Johnson 2011, 92, n. 3). If the bat- 
tlefield mechanism had been decisive, the SPLM/A's military victories would have stopped Kerubino and especially Arok from challenging Garang's leadership in the first place.

By contrast, the external resources argument not only predicts the group's cohesion correctly but its mechanism is also strongly supported by process-tracing evidence. Garang won the initial leadership struggle in mid-1983 because he "proved much more willing to adopt Ethiopian 'advice' than his competitors from the Anya-Nya II" (LeRiche and Arnold 2012, 64). Mengistu Haile Mariam, Ethiopia's communist head of state, wanted to see regime change in Sudan, as President Jaafar Nimairi was backing Ethiopian rebel groups. Garang aligned the SPLM/A's official goals accordingly, writing a manifesto that called for a united socialist Sudan rather than for secession from the north (Johnson 2011, 62-5; Young 2012, 45-6).

Ethiopia also played a key role in suppressing Kerubino's and Arok's leadership challenges. Johnson $(1998,60)$ argues that Garang's decision to help fight anti-Mengistu rebels inside Ethiopia created "a personal tie between Garang and Mengistu," which in return involved “putting Mengistu's security network at Garang's service to contain internal dissent in the SPLA." It was indicative of Ethiopia's importance to the SPLM/A that when Kerubino "attempted to overthrow Garang, he did so by appealing to Mengistu to remove Garang from power" (Johnson 1998, 60). Instead, Kerubino-who had come to Addis Ababa after being lured by an Ethiopian general-was arrested and later transferred to an SPLM/A prison (Madut-Arop 2006, 201-3). In Arok's case, the arrest took place in Sudan, but it partly resulted from incriminating reports by Ethiopian security agents who had been following him (MadutArop 2006, 206-10). In short, up to 1991, Garang "held control of the only significant flow of consistent and reliable external resources" (LeRiche and Arnold 2012, 42).

\section{Exploiting an External Shock: Mengistu's Fall, Khartoum, and the SPLM/A Split, 1991-1992}

On August 28, 1991, around three months after Mengistu was overthrown in Ethiopia, Riek Machar and Lam Akol, two SPLM/A commanders based in Nasir, announced in a radio message to their colleagues that "it has been decided to relieve John Garang from the leadership of the SPLM/A" (reproduced in Akol 2003, 291). However, they failed to garner widespread support for this attempted internal coup (Johnson 2011, 96-7). At the time, Garang was chairing a meeting of the High Command, which Machar, Akol, and their coconspirator Gordon Kong had chosen not to attend. The eight other High Command members who attended, and a ninth who was unable to travel, all swiftly pledged their continued allegiance to Garang via 
radio messages and public statements. In other words, only three out of the thirteen members of the SPLM/A's highest decision-making body were in favor of a coup (Akol 2003, 14-9).

Machar and Akol nonetheless managed to form a breakaway group, initially known as SPLM/A-Nasir, which was backed by the Sudanese government from the very start (Nyaba 2000, 92). Shortly after the coup announcement, its troops engaged in heavy fighting with forces loyal to Garang. Together with their new Anya-Nya II allies and other local militias, Machar and Akol's troops also attacked civilians in Garang's home area (LeRiche and Arnold 2012, 85). After reconciliation talks in Nairobi failed in February 1992, and William Nyuon, who had replaced Kerubino as Garang's deputy in 1987, defected to the SPLM/ANasir in September 1992, it became evident that the organizational split was going to last (Akol 2003, 94; Johnson 2011, 113). Depending on which estimates one believes, around a fifth to perhaps almost a third of the SPLM/A's troops sided with Machar and Akol, making this a relatively large split. ${ }^{18}$

The external resources argument provides the best explanation for the SPLM/A's fragmentation. Both its prediction and mechanism are strongly supported. When Mengistu was overthrown in May 1991 by Ethiopian rebels that Garang had helped fight, the SPLM/A lost its "protected bases, secure supply lines, a source of supply for non-military as well as military goods, and its highly effective radio station" (Johnson 2011, 88). Since all these resources "had been channelled through Garang," their loss "created a favourable climate for a coup" (Rolandsen 2005, 53). Along the same lines, LeRiche and Arnold (2012, 266, n. 85) note that Machar and Akol's "logic was that if Garang's power came from his control over resources acquired from Mengistu, without Mengistu a new power source would be required."

To exploit this external shock, Omar al-Bashir's regime in Khartoum decided to offer its support to Garang's internal rivals (Johnson 1998, 62-5). The offer signaled a change in the distribution of external resources in their favor. ${ }^{19}$ More specifically, Bashir agreed to supply ammunition and to hand over the command of the Anya-Nya II and other pro-government militias to Machar and Akol (Nyaba 2000, 92). Given that Garang continued to have more internal backing and also managed to secure limited material support from other African states shortly after Mengistu's fall (Akol 2001, 194-7; Johnson 2011, 95), however, the over-

\footnotetext{
${ }^{18}$ Human Rights Watch $(1994,101 ; 1998,23)$ suggests that the breakaway group numbered around 10,000 to 20,000, whereas the SPLM/A's size prior to the split has been estimated at anywhere from 55,000 (International Institute for Strategic Studies 1991, 119) to over 70,000 (LeRiche and Arnold 2012, 67).

${ }^{19}$ Seymour $(2014,118-21)$ offers a similar interpretation, focusing on side switching rather than fragmentation.
} 
all distribution of power between him and his internal rivals was roughly balanced at the time of their coup announcement.

The social bases argument also offers important insights. As described above, the SPLM/A was built on weak preexisting horizontal ties. Machar, a Nuer, and Akol, a Shilluk, hardly knew Garang before the war (Akol 2001, 14-5; Scroggins 2004, 177-9, 186-8). All they had in common were doctoral degrees from Western universities-Bradford, Imperial College London, and Iowa State, respectively. Due to these credentials, Garang promoted Machar and Akol to important positions. But he did not consult with them on key decisions, leaving them "impatient with their lack of substantive inclusion and influence" (LeRiche and Arnold 2012, 81). In his inside account of the SPLM/A, Akol $(2001,205)$ calls the High Command "a glittering facade behind which Dr. John Garang would run the movement alone unquestioned." This criticism has some merit: Garang did not convene the High Command in full a single time between 1986 and 1991 (Johnson 2011, 91-2). By the time he did, Machar and Akol had already fallen out with him, and their concerns about being arrested contributed to their rushed coup attempt (Nyaba 2000, 93-4; Madut-Arop 2006, 265-9).

In contrast to external resources and social bases, the battlefield performance argument fails to predict the SPLM/A's fragmentation. Nyaba $(2000,77)$ emphasizes that, between "1989 and 1991, the SPLA had maintained an upper hand against the enemy." Madut-Arop $(2006,259)$ laments that the "split came at a wrong time, especially after achieving strings of victories in the South Sudan." Mengistu's fall forced the group to evacuate its rear bases and "considerably slowed down the SPLA's military momentum, bringing it to a halt in some places" (Johnson and Prunier 1993, 138). Yet Garang's SPLM/A began to lose significant stretches of Sudanese territory only after the attempted coup (LeRiche and Arnold 2012, 856 , 90). Seymour (2014, 120-1) also notes that, despite subsequent ethnic polarization pitting Dinka against Nuer, the split did not occur simply along subgroup lines.

Table 2 summarizes the findings from both SPLM/A case study periods. Although there is support for the prediction and the mechanism of the social bases argument in the 19911992 period, the fact that the SPLM/A's weak preexisting horizontal ties did not cause the group to fragment in its first eight years highlights the superior explanatory power of external resources. By firmly backing Garang against his internal rivals, Ethiopia managed to hold the group together. Once Mengistu was overthrown, however, "supplies dried up, and all the bottled-up contradictions in the SPLM/A came to the fore" (LeRiche and Arnold 2012, 54). 
TABLE 2. SPLM/A Case Study Findings

\begin{tabular}{lllll}
\hline Explanation & \multicolumn{2}{l}{ Period I } & (1983-90): Cohesion & \multicolumn{2}{l}{ Period II (1991-92): Fragmentation } \\
& Correct & Evidence for & Correct & Evidence for \\
& Prediction? & Mechanism? & Prediction? & Mechanism? \\
\hline Social Bases & No & - & Yes & Strong \\
Battlefield Performance & Yes & Mixed & No & - \\
External Resources & Yes & Strong & Yes & Strong \\
\hline
\end{tabular}

Changing Course: Iranian Pragmatism and Hezbollah's “Lebanonization,” 1991-1996

The year 1991 marked “a critical juncture” (Ranstorp 1998, 120) for Lebanon's Hezbollah. Literally the Party of God, this Shiite insurgent group emerged in the 1980s with crucial support from Iran and Syria. Both states saw Hezbollah as a means to indirectly combat Israeli and American military forces in the context of the Lebanese civil war (Ranstorp 1997, 114; DeVore 2012, 91-9). In 1991, two major changes affected the group. First, Syria became determined to put an end to intra-Lebanese fighting. The Treaty of Brotherhood, Cooperation and Coordination, signed in May 1991, institutionalized its sway over Lebanon (Hinnebusch 1998, 145-50; Norton 2014, 97-8). Second, the death of Iran's Supreme Leader, Ruhollah Khomeini, in 1989 weakened the regime's revolutionist faction and led to a more pragmatic foreign policy under Ali Khamenei and President Hashemi Rafsanjani (Hamzeh 2004, 109). These developments together resulted in a quid pro quo between Hezbollah, Syria, and Iran: Hezbollah agreed not to challenge the new Lebanese regime and in exchange was allowed to continue its guerrilla warfare against Israel's occupation of southern Lebanon (Ranstorp 1994, 313-4).

Hezbollah's decision to participate in the 1992 parliamentary elections consolidated the party's “Lebanonization" (Ranstorp 1998, 104). It also marked the beginning of a serious internal rivalry within the organization. In 1991, secretary-general Subhi al-Tufayli was replaced by the more pragmatic Abbas al-Musawi, who was assassinated by Israel and succeeded by Hasan Nasrallah one year later. Both al-Musawi and Nasrallah stood for a majority that favored Hezbollah's accommodation with the Lebanese confessional system. Al-Tufayli, by contrast, represented a smaller camp of radicals who argued that this would distract Hezbollah from its jihad against Israel and undermine its ultimate goal of establishing an Islamic order (Hamzeh 2004, 109-10; Harik 2004, 56-7). Following Nasrallah's election, al-Tufayli refused to take up his seat on the group's consultative council. Instead, he "withdrew to his 
hometown in the Biqa "Valley to rally his supporters" (Kramer 1995, 124). Although he did not split with Hezbollah until 1997, al-Tufayli publicly criticized al-Musawi's and Nasrallah's leadership throughout the 1991-1996 period (Qassem 2010, 221).

The social bases argument correctly predicts Hezbollah's organizational cohesion in this period, but the evidence for its mechanism is mixed. The various Shiite movements that merged into Hezbollah in 1982 "could trace their origins to the activities during the 1960-70s of the Shi'i religious academies in the south of Iraq" (Ranstorp 1997, 26). Al-Tufayli, alMusawi, and Nasrallah all studied theology in Najaf, where Khomeini was a lecturer up until 1978 (Ranstorp 1997, 46; Harik 2004, 53). Their time in Najaf enabled them and their fellow students to forge "close-knit relationships and personal networks" (Ranstorp 1997, 27) prior to entering the Lebanese civil war. Each of them were also able to draw on local support networks in their respective hometowns (Ranstorp 1997, 33-4; Hamzeh 2004, 88). In other words, Hezbollah was built on strong horizontal and vertical ties. The internal rivalry that nevertheless emerged among its leading clerics thus casts doubt on the explanatory power of preexisting social bases.

Similarly, there is mixed evidence for the argument that battlefield wins explain cohesion, despite its correct prediction. Drawing on Hezbollah's media outlets, Hamzeh (2004, 89) reports that its armed wing, the Islamic Resistance, launched 1,030 militant operations against Israeli forces and their local allies, the South Lebanon Army, between 1990 and 1995, a tenfold increase compared to 1985-1989. Israel responded with two large-scale military operations in 1993 and 1996, codenamed Accountability and Grapes of Wrath. Both, however, proved ineffective in reducing Hezbollah's guerrilla activities (Maoz 2009, 220). If the battlefield mechanism had played a decisive role, the group's relatively successful military record would have appeased al-Tufayli and ended his opposition to Nasrallah.

By contrast, both the prediction and the mechanism of the external resources argument find strong support. Al-Musawi's takeover from al-Tufayli in 1991 was largely a result of the new Iranian leadership's discontent with al-Tufayli's stubborn radicalism. To strengthen the pragmatists within Hezbollah, Supreme Leader Khamenei first endorsed al-Musawi and then, in 1992, Nasrallah (Hamzeh 2004, 110-1). Meanwhile, President Rafsanjani successfully marginalized Ali Akbar Mohtashami, Iran's ambassador to Damascus from 1982 to 1985 and then its interior minister until 1989, who had supported al-Tufayli in the past and continued to hold an extreme view of Hezbollah's purpose (Kramer 1995, 125). Rafsanjani also replaced foreign ministry officials in Tehran and Revolutionary Guard units in Lebanon who were seen as too radical, thus ensuring that all of Iran's support would subsequently be channeled 
to al-Musawi and Nasrallah (Ranstorp 1998, 118; Chehabi 2003, 289). Iranian funding was estimated at $\$ 60$ million a year in the early 1990s (Kramer 1995, 125).

Although Syria had supported the creation of Hezbollah in 1982, it soon believed the group's Islamic vision to be at odds with its own objective of rebuilding a pluralistic Lebanon. This led to tensions between Syria and Hezbollah as well as between Syria and Iran, which were overcome only after Khamenei and Rafsanjani threw their weight behind Hezbollah's pragmatists (Ranstorp 1997, 119-30). In contrast to al-Tufayli, al-Musawi and Nasrallah understood that "in return for Syria's support for its unique role at the head of the Islamic resistance in the south," the group would need to "tailor its activities to serve Syrian strategy in the conflict with Israel" (Ehteshami and Hinnebusch 1997, 137). Up until 1996, it was therefore in Syria's interest to back Nasrallah's leadership.

\section{Punishing Nasrallah: Syria, Hezbollah, and the "Revolution of the Hungry," 1997-1999}

The simmering internal rivalry between Nasrallah and al-Tufayli escalated in 1997, when the latter launched the "Revolution of the Hungry" in the Beqaa Valley (Norton 2014, 106). AlTufayli first called for a civil disobedience campaign, then also for road blockades. He did so, as Nasrallah's deputy highlights, "without resorting to any coordination or even deliberations with Hizbullah" (Qassem 2010, 222). Despite being banned by the government, the opening rally in Baalbek on July 4 attracted at least 3,000 supporters and ended peacefully (Karam 1997). Officially focused on social justice for Lebanon's poorest citizens, it was widely believed that the actual goal of al-Tufayli's campaign was "to split Hizbullah and at least gain power over its constituency in the Ba albek-Hirmil area" (Hamzeh 2004, 111).

As time went by, al-Tufayli's messages to his followers became increasingly radical, openly calling for violence against state officials (Harris 2000, 522-3; Azani 2011, 132). In January 1998, he further provoked Nasrallah by holding a rally on Jerusalem Day in the same square in Baalbek in which Hezbollah traditionally hosted an event. In response, the leadership expelled al-Tufayli from Hezbollah, arguing that his campaign "was of a divisive and independent nature, while any field movement ought to have been bound by the Hizbullah Council decision" (Qassem 2010, 222). Incensed, al-Tufayli and around 200 armed followers occupied Hezbollah's religious school in Baalbek, leading to a shootout with the Lebanese army (Norton 1998, 95). While some of its members were killed or arrested, the bulk of alTufayli's breakaway group — which altogether only amounted to perhaps five percent of Hez- 
bollah's troops - managed to escape to the mountains near his hometown, Brital. ${ }^{20}$ There, they reportedly prepared "for a last stand" (Karam 1998).

However, such a confrontation never occurred. Instead, al-Tufayli reappeared in public one year later, and his rank and file, "swelled with new recruits of disaffected Hezbollah militiamen," carried on with sporadic operations against Nasrallah's group, seizing one of Hezbollah's major weapons depots in April 1999 (Middle East Intelligence Bulletin 1999). What explains this surprising survival of the splinter group? A closer look reveals that external resources played a decisive role, determining the trajectory of al-Tufayli's challenge to Nasrallah in three ways.

First, Syria enabled the launch of the Revolution of the Hungry to punish Nasrallah's agency slack and to remind their Iranian allies that "despite their close relations with the Nasrallah clan the latter must toe the line dictated by Damascus" (Intelligence Newsletter 1999). ${ }^{21}$ In the run-up to the 1996 parliamentary elections, Nasrallah had initially refused Syria's suggestion to reduce Hezbollah's share of seats in the Shiite bloc from twelve to nine (Harris 1998, 489). When, shortly afterwards and in the wake of Israel's Grapes of Wrath operation, Iran sent a vast amount of weapons to replenish Hezbollah's stocks, Syrian officials thus had good reason to worry about the "psychological and material maneuverability" provided to Nasrallah (Harris 2000, 530). Their support for al-Tufayli served as a warning to Nasrallah, signaling his "vulnerability within the Shi 'i community" (Harris 2000, 522).

Second, when al-Tufayli's actions themselves got out of hand and began to threaten stability in the Beqaa Valley, Syria cut him down to size by asking the Lebanese army to force an end to his occupation of Hezbollah's religious school in January 1998. Iran supported this decision (Harris 2001, 411-2). Analysts emphasized that al-Tufayli had "badly miscalculated the limits of his rebellion," thinking that "he had the unlimited support of Damascus" and thus would perhaps be able to "achieve an internal coup d'état within the Hezbollah leadership" (Dagher 1998). Such a coup, however, would have led to clashes bound to undermine the armed resistance against Israel, and it would have seriously jeopardized Syria's strategic relationship with Iran. These potential outcomes were unacceptable for Damascus (Mideast Mirror 1998a; 1998b).

\footnotetext{
${ }^{20}$ Prior to the split, Hezbollah had a professional core of up to 500 fighters and an estimated 3,000 supporters (Demick 1997; International Institute for Strategic Studies 1997, 132). Assuming that almost all of al-Tufayli's 200 armed followers belonged to these 3,500 troops, one arrives at a splinter size of around five percent.

${ }^{21}$ On the argument that al-Tufayli could not have launched his campaign without Syrian consent or encouragement, see also Mideast Mirror (1998b); Norton (1998, 94); Ranstorp (1998, 132); Harris (2000, 522). Syria had up to 35,000 troops in Lebanon after 1989, many of them stationed in the Beqaa Valley (Ranstorp 1998, 117).
} 
Third, Syria was instrumental in ensuring that the Lebanese authorities stopped their pursuit of al-Tufayli's breakaway group, which allowed him to return to the political scene (Middle East Intelligence Bulletin 1999; Azani 2011, 134). After all, it was useful to retain him as a potential "card against the Lebanese regime and Hizballah" (Zisser 2000, 38). Syria's decision to divide its support—backing Nasrallah in Hezbollah's fight against Israel while also keeping al-Tufayli's group alive-followed the same divide-and-rule strategy that had led to the fragmentation of the Shiite Amal militia in 1982 (Norton 1987, 100-1).

In short, the external resources argument finds strong support. By contrast, neither social bases nor battlefield performance predict Hezbollah's split in the 1997-1999 period. The group's preexisting horizontal ties obviously did not change, and its military record actually improved. Harris $(2000,53)$ estimates that the ratio of Israeli and Hezbollah combat losses in 1997 (1:1.7) was more favorable than in 1995 (1:3) and 1996 (1:2). Moreover, the group launched 4,928 militant operations from 1996 to 2000, almost five times as many as in 19901995. Nearly a third of them were carried out in 1999 alone (Hamzeh 2004, 89-90).

Table 3 summarizes the findings from the Hezbollah case study. It clearly shows the added value of studying external resource allocation, which emerges as the only explanation that accounts for both cohesion and fragmentation over time.

TABLE 3. Hezbollah Case Study Findings

\begin{tabular}{lllll}
\hline Explanation & \multicolumn{2}{l}{ Period I (1991-96): Cohesion } & \multicolumn{2}{l}{ Period II (1997-99): Fragmentation } \\
& Correct & Evidence for & Correct & Evidence for \\
& Prediction? & Mechanism? & Prediction? & Mechanism? \\
\hline Social Bases & Yes & Mixed & No & - \\
Battlefield Performance & Yes & Mixed & No & - \\
External Resources & Yes & Strong & Yes & Strong \\
\hline
\end{tabular}

\section{Conclusion}

Many recent civil wars-from Iraq, Libya, and Syria to Ukraine-involve external state sponsorship of insurgent groups. This highlights the continued importance of understanding the effects of sponsorship on conflict dynamics (Mumford 2013, 98-9; International Crisis Group 2015, 5-8). In this article, I show that the allocation of external resources can play a major role in explaining why some armed groups stick together while others fall apart. By focusing on whether resources are channeled to existing rebel leaders or to their internal rivals, I resolve confusion about the effects of different numbers of state sponsors. I also 
demonstrate that the impact of external resources sometimes depends more on the choices of state sponsors than on a group's preexisting social bases.

However, my purpose is not to replace existing theories but to establish state sponsorship as one major explanation alongside others. Future research should either integrate external resource allocation into more complex multicausal accounts or consider it as a competing explanation. I argue above that if sponsors attempt to foster splits, they are likely to outweigh counteracting factors that decrease the chance of fragmentation. Attempts to strengthen cohesion, on the other hand, will likely counteract factors that increase the chance of fragmentation only if the involvement of sponsors is as extensive as, for instance, recent Russian troop support to separatist groups in eastern Ukraine. However, Ethiopia's ability to hold the SPLM/A together for about eight years, despite both the group's divided social bases and the absence of Ethiopian troops on Sudanese territory, suggests the need for further investigation of how different factors interact.

My analysis also suggests that existing cross-national datasets on external support simply cannot solve the puzzle of the differential impact of state sponsorship on insurgent cohesion. They only code the types of resources that groups received, without identifying to whom within the group these resources were allocated. To evaluate the study's hypotheses across space and time, the impressive recent advances in collecting time-series data on state support (Högbladh et al. 2011; Maoz and San-Akca 2012) will require augmentation, at least with a dummy variable indicating whether or not the resources were clearly channeled to an existing group leader. While this is a serious data challenge, the case studies presented above suggest that existing sources can supply such information.

The article raises three other topics that warrant further research. First, I show that rivalries occur even in highly effective insurgent groups, but my theory does not itself explain the origins of intra-group rivalries. This limitation also applies to Seymour's $(2014,103)$ opportunistic theory of alignments, which focuses on local political rivalries without explaining how they emerge. To further the study of wartime rivalries more broadly, we should investigate their causes both within and across groups. While this article establishes the conditions under which intra-group rivalries are most likely to result in organizational splits or internal coups, there may be other determinants of why some elite disagreements lead to infighting whereas others are resolved peacefully.

Second, my theory treats a rebel leader's agency slack as an independent variable that explains why state sponsors reallocate at least some of their resources to an intra-group rival. However, a leader's undesired behavior may also lead sponsors to shift their support to an 
extra-group rival, that is, another rebel group from the same country. State sponsors can sometimes choose from a pool of rebel groups, just as rebel groups can sometimes choose from a pool of potential sponsors. Future research should build on existing insights from principal-agent theory (Hawkins and Jacoby 2006, 203-5; Tamm and Snidal 2014, 136) to explain how variation in the size of these two pools can affect both the likelihood of a rebel leader's agency slack and the way in which it will be punished.

Third, I note that organizational cohesion and military effectiveness are analytically separate issues. This raises the question of whether or not the causal pathways connecting external support to effectiveness differ from the links between external support and cohesion. For example, state sponsors that use foreign rebel groups primarily as bargaining chips in militarized interstate disputes may want their agents to remain cohesive-so that their orders are more likely to be followed-but they may not want them to be effective enough to become independent. Having established the importance of principal-agent theory for explaining the impact of state sponsors on cohesion, a logical next step involves applying insights from that theory to the study of insurgent effectiveness.

The findings of this article also matter for international efforts to resolve conflicts featuring outside interference. International mediators need to engage rebel leaders and their state sponsors simultaneously, as sponsors who disagree with a leader's negotiation strategy are likely to spoil potential peace deals by empowering the leader's internal rivals. An alternative to engagement is to exert sufficient international pressure on sponsors so that they terminate their support for the rebel group altogether. Such pressure, however, may have the unintended effect of endangering civilians by increasing the risk of insurgent fragmentation. The SPLM/A case study shows that a rebel leader's ability to contain internal rivals can be undermined by a loss of external resources and that subsequent infighting may involve the systematic targeting of civilians, especially in the case of interethnic rivalries. In short, policymakers interested in conflict resolution should pay close attention both to rivalries within rebel groups and to how state sponsors affect them.

\section{References}

AKOL, LAM. 2001. SPLM/SPLA: Inside an African Revolution. Khartoum: Khartoum University Press.

AKOL, LAM. 2003. SPLM/SPLA: The Nasir Declaration. New York: iUniverse.

AZANI, EITAN. 2011. Hezbollah: The Story of the Party of God: From Revolution to Institutionalization. Basingstoke: Palgrave Macmillan. 
BAKKE, KRISTIN M. 2014. "Help Wanted? The Mixed Record of Foreign Fighters in Domestic Insurgencies.” International Security 38(4): 150-87.

BakKe, Kristin M., Kathleen Gallagher Cunningham, and Lee J. M. Seymour. 2012. "A Plague of Initials: Fragmentation, Cohesion, and Infighting in Civil Wars." Perspectives on Politics 10(2): 265-83.

BAPAT, NEVIN A. 2012. "Understanding State Sponsorship of Militant Groups." British Journal of Political Science 42(1): 1-29.

Bennett, Andrew, And JefFrey T. Checkel. 2015. "Process Tracing: From Philosophical Roots to Best Practices." In Process Tracing: From Metaphor to Analytic Tool, eds. Andrew Bennett and Jeffrey T. Checkel, 3-37. Cambridge: Cambridge University Press.

Bose, SumAnTRA. 2007. "The JKLF and JKHM: The Kashmir Insurgents.” In Terror, Insurgency, and the State: Ending Protracted Conflicts, eds. Marianne Heiberg, Brendan O'Leary, and John Tirman, 229-55. Philadelphia, PA: University of Pennsylvania Press.

Burr, J. Millard, And Robert O. Collins. 1999. Africa's Thirty Years War: Libya, Chad, and the Sudan, 1963-1993. Boulder, CO: Westview Press.

Byman, Daniel, Peter Chalk, Bruce Hoffman, William Rosenau, and David BRANNAN. 2001. Trends in Outside Support for Insurgent Movements. Santa Monica, CA: RAND.

Byman, Daniel, AND SARAH E. KREPS. 2010. "Agents of Destruction? Applying PrincipalAgent Analysis to State-Sponsored Terrorism.” International Studies Perspectives 11(1): 1-18.

Carey, Sabine C., Neil J. Mitchell, And Will Lowe. 2013. "States, the Security Sector, and the Monopoly of Violence: A New Database on Pro-Government Militias." Journal of Peace Research 50(2): 249-58.

CheHABi, H. E. 2003. "Iran and Lebanon after Khomeini." In Distant Relations: Iran and Lebanon in the Last 500 Years, ed. H. E. Chehabi, 287-308. London: I.B. Tauris.

Christia, Fotini. 2012. Alliance Formation in Civil Wars. Cambridge: Cambridge University Press.

Cunningham, David E. 2010. "Blocking Resolution: How External States Can Prolong Civil Wars." Journal of Peace Research 47(2): 115-27.

Cunningham, David E. 2011. Barriers to Peace in Civil War. Cambridge: Cambridge University Press.

Cunningham, David E., Kristian Skrede Gleditsch, and Idean Salehyan. 2013. "NonState Actors in Civil Wars: A New Dataset." Conflict Management and Peace Science 30(5): 516-31.

DAGHER, CAROLE. 1998. "Letter from Lebanon: Syria and Iran Make Significant Gestures in Lebanon." The Washington Report on Middle East Affairs 17(3): 55.

DEMICK, BARBARA. 1997. "In Lebanon, Israel Battles a Shadowy Enemy." The Philadelphia Inquirer, September 15.

DeVore, MARC R. 2012. "Exploring the Iran-Hezbollah Relationship: A Case Study of How State Sponsorship Affects Terrorist Group Decision-Making." Perspectives on Terrorism 6(4-5): 85-107.

Ehteshami, Anoushiravan, And RAYMond Hinnebusch. 1997. Syria and Iran: Middle Powers in a Penetrated Regional System. London: Routledge. 
ELLIS, STEPHEN. 1998. "Liberia's Warlord Insurgency." In African Guerrillas, ed. Christopher Clapham, 155-71. Oxford: James Currey.

Ellis, StePHEn. 1999. The Mask of Anarchy: The Destruction of Liberia and the Religious Dimensions of an African Civil War. London: Hurst \& Co.

Englebert, PIERRE. 1996. Burkina Faso: Unsteady Statehood in West Africa. Boulder, CO: Westview Press.

Felter, Joseph, AND Brian Fishman. 2008. "Iranian Strategy in Iraq: Politics and 'Other Means." Occasional Paper Series. West Point, NY: Combating Terrorism Center.

George, Alexander L., And Andrew Bennett. 2005. Case Studies and Theory Development in the Social Sciences. Cambridge, MA: MIT Press.

GILBERT, DENNIS. 1988. Sandinistas: The Party and the Revolution. Oxford: Basil Blackwell.

Glaser, Charles L. 2010. Rational Theory of International Politics: The Logic of Competition and Cooperation. Princeton, NJ: Princeton University Press.

HamzeH, Ahmad Nizar. 2004. In the Path of Hizbullah. Syracuse, NY: Syracuse University Press.

HARIK, Judith PALMER. 2004. Hezbollah: The Changing Face of Terrorism. London: I.B. Tauris.

HaRris, William W. 1998. "Lebanon." In Middle East Contemporary Survey. Volume XX: 1996, ed. Bruce Maddy-Weitzman, 472-509. Boulder, CO: Westview Press.

Harris, William W. 2000. "Lebanon." In Middle East Contemporary Survey. Volume XXI: 1997, ed. Bruce Maddy-Weitzman, 509-42. Boulder, CO: Westview Press.

HaRris, WILliam W. 2001. "Lebanon." In Middle East Contemporary Survey. Volume XXII: 1998, ed. Bruce Maddy-Weitzman, 407-34. Boulder, CO: Westview Press.

Hawkins, Darren G., AND Wade Jacoby. 2006. "How Agents Matter." In Delegation and Agency in International Organizations, eds. Darren G. Hawkins, David A. Lake, Daniel L. Nielson, and Michael J. Tierney, 199-228. Cambridge: Cambridge University Press.

Hawkins, Darren G., David A. Lake, Daniel L. Nielson, And Michael J. Tierney. 2006. "Delegation Under Anarchy: States, International Organizations, and Principal-Agent Theory." In Delegation and Agency in International Organizations, eds. Darren G. Hawkins, David A. Lake, Daniel L. Nielson, and Michael J. Tierney, 3-38. Cambridge: Cambridge University Press.

Heger, Lindsay, and Idean Salehyan. 2007. "Ruthless Rulers: Coalition Size and the Severity of Civil Conflict." International Studies Quarterly 51(2): 385-403.

Hinnebusch, Raymond. 1998. "Pax-Syriana? The Origins, Causes and Consequences of Syria's Role in Lebanon." Mediterranean Politics 3(1): 137-60.

Högbladh, Stina, Therése Pettersson, And LotTa Themnér. 2011. "External Support in Armed Conflict 1975-2009: Presenting New Data." Paper presented at the Annual Convention of the International Studies Association, Montreal, Canada.

HoviL, LuCY, AND ERIC WERKER. 2005. "Portrait of a Failed Rebellion: An Account of Rational, Sub-Optimal Violence in Western Uganda." Rationality and Society 17(1): 5-34.

Human Rights Watch. 1994. "Civilian Devastation: Abuses by All Parties in the War in Southern Sudan.” New York. June.

Human Rights Watch. 1998. "Sudan: Global Trade, Local Impact: Arms Transfers to All Sides in the Civil War in Sudan." New York. August. 
InTELligence Newsletter. 1999. "In-Fighting Among Hezbollah Bosses.” No. 358. May 13.

InTERNATIONAL CRISIS GROUP. 2006. "Iraq's Muqtada Al-Sadr: Spoiler or Stabiliser?” Amman/Brussels. July 11.

InTERnational CRisis Group. 2009. "Congo: Five Priorities for a Peacebuilding Strategy." Nairobi/Brussels. May 11.

InTERnATIONAL CRISIS GROUP. 2015. "The Ukraine Crisis: Risks of Renewed Military Conflict after Minsk II.” Kyiv/Brussels. April 1.

INTERNATIONAL InSTITUTE FOR STRATEGIC STUDIES. 1991. The Military Balance 1991/1992. London.

InTERNATIONAL INSTITUTE FOR STRATEGIC STUDIES. 1997. The Military Balance 1997/1998. London.

Johnson, Douglas H. 1998. "The Sudan People's Liberation Army and the Problem of Factionalism." In African Guerrillas, ed. Christopher Clapham, 53-72. Oxford: James Currey.

Johnson, Douglas H. 2011. The Root Causes of Sudan's Civil Wars: Peace or Truce. Revised edition. Oxford: James Curry.

Johnson, Douglas H., AND GÉRARD PRUniER. 1993. "The Foundation and Expansion of the Sudan People's Liberation Army." In Civil War in the Sudan, eds. M.W. Daly and Ahmad Alawad Sikainga, 117-41. London: British Academic Press.

JOHnSTON, PATRICK. 2008. "The Geography of Insurgent Organization and its Consequences for Civil Wars: Evidence from Liberia and Sierra Leone.” Security Studies 17(1): 10737.

Kapur, S. Paul, And Sumit Ganguly. 2012. "The Jihad Paradox: Pakistan and Islamist Militancy in South Asia.” International Security 37(1): 111-41.

KarAm, ZeINA. 1997. "Rally Comes Off Peacefully Amid Heavy Army Deployment." Associated Press, July 4.

KARAM, ZEINA. 1998. "Tense Standoff as Muslim Militants Bury Leader.” Associated Press, February 1.

KENNY, PAUL D. 2010. "Structural Integrity and Cohesion in Insurgent Organizations: Evidence from Protracted Conflicts in Ireland and Burma." International Studies Review 12(4): 533-55.

KrAmER, MARTIN. 1995. "Rallying Around Islam." In Middle East Contemporary Survey. Volume XVII: 1993, ed. Ami Ayalon, 109-53. Boulder, CO: Westview Press.

Krause, Peter. 2013/2014. "The Structure of Success: How the Internal Distribution of Power Drives Armed Group Behavior and National Movement Effectiveness." International Security 38(3): 72-116.

LeRiche, MAtThew, And MATTHEW ARnOld. 2012. South Sudan: From Revolution to Independence. London: Hurst \& Co.

Lesch, Ann Mosely. 1998. The Sudan-Contested National Identities. Bloomington, IN: Indiana University Press.

LiCHBACH, MARK IRving. 1995. The Rebel's Dilemma. Ann Arbor, MI: University of Michigan Press.

LidOW, NiCHOLAI HART. 2011. "Violent Order: Rebel Organization and Liberia's Civil War." $\mathrm{PhD}$ dissertation, Stanford University. 
Madut-Arop, Arop. 2006. Sudan's Painful Road to Peace: A Full Story of the Founding and Development of the SPLM/SPLA. Charleston, SC: BookSurge.

MaOz, ZEEv. 2009. Defending the Holy Land: A Critical Analysis of Israel's Security and Foreign Policy. Ann Arbor, MI: Michigan University Press.

MaOZ, ZeEV, AND Belgin SAN-AKCA. 2012. "Rivalry and State Support of Non-State Armed Groups (NAGs), 1946-2001.” International Studies Quarterly 56(4): 720-34.

Mclauchlin, Theodore, and Wendy Pearlman. 2012. "Out-Group Conflict, In-Group Unity? Exploring the Effect of Repression on Intramovement Cooperation." Journal of Conflict Resolution 56(1): 41-66.

Middle East InTElligence Bulletin. 1999. "Tufaili Returns to Lebanese Political Scene." Vol. 1, No. 12. December.

Mideast MirRor. 1998a. "Syria, Iran and Lebanon vs Tufaili." Vol. 12, No. 21. February 2.

MideAST MirRor. 1998b. "How Lebanon's Tufaili Fell Foul of Local and Regional Sponsors." Vol. 12, No. 26. February 9.

Mumford, Andrew. 2013. Proxy Warfare. Cambridge: Polity Press.

Nolutshungu, SAm C. 1996. Limits of Anarchy: Intervention and State Formation in Chad. Charlottesville, VA: University Press of Virginia.

Norton, Augustus Richard. 1987. Amal and the Shi 'a: Struggle for the Soul of Lebanon. Austin, TX: University of Texas Press.

Norton, Augustus RichARD. 1998. "Walking between Raindrops: Hizballah in Lebanon." Mediterranean Politics 3(1): 81-102.

Norton, Augustus Richard. 2014. Hezbollah: A Short History. Princeton, NJ: Princeton University Press.

Nyaba, Peter Adwok. 2000. The Politics of Liberation in South Sudan: An Insider's View. Second edition. Kampala: Fountain Publishers.

Olson Lounsbery, Marie, And Alethia H. CoOK. 2011. "Rebellion, Mediation, and Group Change: An Empirical Investigation of Competing Hypotheses." Journal of Peace Research 48(1): 73-84.

Pearlman, Wendy. 2008/2009. "Spoiling Inside and Out: Internal Political Contestation and the Middle East Peace Process." International Security 33(3): 79-109.

Pearlman, Wendy. 2011. Violence, Nonviolence, and the Palestinian National Movement. Cambridge: Cambridge University Press.

Pearlman, Wendy, and Kathleen Gallagher Cunningham. 2012. "Nonstate Actors, Fragmentation, and Conflict Processes." Journal of Conflict Resolution 56(1): 3-15.

PRUnier, GÉRARD. 2009. Africa's World War: Congo, the Rwandan Genocide, and the Making of a Continental Catastrophe. New York: Oxford University Press.

QASSEM, NAIM. 2010. Hizbullah: The Story from Within. Updated paperback edition. London: Saqi.

RANSTORP, Magnus. 1994. "Hizbollah's Command Leadership: Its Structure, DecisionMaking and Relationship with Iranian Clergy and Institutions." Terrorism and Political Violence 6(3): 303-39.

Ranstorp, Magnus. 1997. Hizb'allah in Lebanon: The Politics of the Western Hostage Crisis. Basingstoke: Macmillan.

RANSTORP, MAGnUS. 1998. “The Strategy and Tactics of Hizballah's Current 'Lebanonization Process." Mediterranean Politics 3(1): 103-34. 
RAshid, AhMed. 2010. Taliban: The Power of Militant Islam in Afghanistan and Beyond. London: I.B. Tauris.

Rolandsen, Øystein H. 2005. Guerrilla Government: Political Changes in the Southern Sudan during the 1990s. Uppsala: Nordiska Afrikainstitutet.

SALEHYAN, IDEAN. 2010. "The Delegation of War to Rebel Organizations." Journal of Conflict Resolution 54(3): 493-515.

Salehyan, Idean, Kristian Skrede Gleditsch, and David E. Cunningham. 2011. "Explaining External Support for Insurgent Groups." International Organization 65(4): 709-44.

SAYIGH, YeZID. 1997. Armed Struggle and the Search for State: The Palestinian National Movement, 1949-1993. Oxford: Oxford University Press.

Schimmelfennig, FranK. 2015. "Efficient Process Tracing: Analyzing the Causal Mechanisms of European Integration." In Process Tracing: From Metaphor to Analytic Tool, eds. Andrew Bennett and Jeffrey T. Checkel, 98-125. Cambridge: Cambridge University Press.

Schubiger, Livia IsABella. 2015. "One for All? State Violence and Insurgent Cohesion." Paper presented at the Annual Convention of the International Studies Association, New Orleans, LA.

Scroggins, Deborah. 2004. Emma's War: Love, Betrayal and Death in the Sudan. London: Harper Perennial.

Seymour, LeE J. M. 2014. "Why Factions Switch Sides: Rivalry, Patronage and Realignment in Sudan." International Security 39(2): 92-131.

SinNo, ABDUlKader H. 2008. Organizations at War in Afghanistan and Beyond. Ithaca, NY: Cornell University Press.

StAnILAND, PAUl. 2012. "Organizing Insurgency: Networks, Resources, and Rebellion in South Asia." International Security 37(1): 142-77.

StAnILAND, PAUl. 2014. Networks of Rebellion: Explaining Insurgent Cohesion and Collapse. Ithaca, NY: Cornell University Press.

Tamm, Henning, And Duncan Snidal. 2014. "Rational Choice and Principal-Agent Theory." In International Organization and Global Governance, eds. Thomas Weiss and Rorden Wilkinson, 132-43. London: Routledge.

TARrow, Sidney G. 2011. Power in Movement: Social Movements and Contentious Politics. Revised and updated third edition. Cambridge: Cambridge University Press.

UpPSala Conflict Data Program. 2014. "UCDP Actor Dataset 2.2-2014.” Uppsala University. Available at http://www.pcr.uu.se/research/ucdp/datasets/ucdp_actor_dataset/. (Accessed August 7, 2015.)

Vlassenroot, Koen, And Timothy RaeymaeKers. 2009. "Briefing: Kivu's Intractable Security Conundrum.” African Affairs 108(432): 475-84.

Woldemariam, Michael. 2016. "Battlefield Outcomes and Rebel Cohesion: Lessons from the Eritrean Independence War." Terrorism and Political Violence 28(1): 135-56.

Young, John. 1997. Peasant Revolution in Ethiopia: The Tigray People's Liberation Front, 1975-1991. Cambridge: Cambridge University Press.

Young, John. 2012. The Fate of Sudan: The Origins and Consequences of a Flawed Peace Process. London: Zed Books.

ZISSER, EYAL. 2000. "Hizballah: New Course or Continued Warfare." Middle East Review of International Affairs 4(3): 32-42. 